\title{
ILCEA
}

Revue de l'Institut des langues et cultures

d'Europe, Amérique, Afrique, Asie et Australie

$31 \mid 2018$

Récits fictionnels et non fictionnels liés à des

communautés professionnelles et à des groupes spécialisés

\section{Entrepreneurial Storytelling in Organizational Discourse}

Le récit « entrepreneurial » dans le discours organisationnel

\section{Birgitta Borghoff}

\section{OpenEdition}

\section{Journals}

Electronic version

URL: http://journals.openedition.org/ilcea/4700

DOI: 10.4000/ilcea.4700

ISSN: 2101-0609

Publisher

UGA Éditions/Université Grenoble Alpes

Printed version

ISBN: 978-2-37747-043-3

ISSN: $1639-6073$

\section{Electronic reference}

Birgitta Borghoff, « Entrepreneurial Storytelling in Organizational Discourse », ILCEA [Online], 31 | 2018,

Online since 06 March 2018, connection on 01 May 2019. URL : http://journals.openedition.org/

ilcea/4700 ; DOI : 10.4000/ilcea.4700

This text was automatically generated on 1 May 2019.

(C) ILCEA 


\title{
Entrepreneurial Storytelling in Organizational Discourse
}

Le récit « entrepreneurial » dans le discours organisationnel

\author{
Birgitta Borghoff
}

\section{Introduction: organizational practice as a communicative task}

1 The next society, which the sociologist Baecker (2007) anticipated in 2007, has long since become an everyday reality. It does not focus on tradition or purpose-oriented organizations which provide for the satisfaction of needs or ensure that the interests of people are preserved. It is rather the ubiquitous happening of communicative networking through which value creation and social structure are either developed or can fail. In this context, know-how and technology, especially for digital networking and transformation (Bounfour, 2016; Abolhassan, 2017), have become a decisive asset.

2 Under these conditions the understanding of organizations and their communication is inevitably and constantly changing. Based on international theories and surveys among managers, communication has become the key to value creation (e.g. de Beer, 2014; Zerfass et al., 2013). This is due to the fact that the value of capital generated by an organization can increase or decrease depending on what the leaders and employees say and do (ibid.).

3 Against this background, the foundation and management of organizations are genuinely communicative tasks. Corresponding practice routines such as leadership, management and counseling are stabilized by communicative competences (Fairhurst, 2007; Cooren, 2015; Rüegg-Stürm \& Grand, 2015; Stücheli-Herlach, 2015), as well as the creation of organizations as a routine of entrepreneurship (Gartner, 2004a, 2007, 2010; Hjorth \& Steyaert, 2004; Stayaert, 2004, 2007).

4 Likewise, the management of cultural organizations, artistic projects and businesses in the creative industries are affected by routines of entrepreneurship (Klein, 2009, 2011; 
Hausmann, 2012, 2017; Konrad, 2006, 2010, 2013). The management of cultural and creative organizations has to permanently prove itself in terms of the long-term controversy about political promotion and funding, commercial use, the digitalization of cultural mediation, social responsibility and aesthetic innovation.

Two case studies on entrepreneurial storytelling in the cultural and creative industries sector provide an insight into the process of project and organizational foundation under conditions described above. This research is based on a strategy-as-practice approach (Whittington, 2006) whilst investigating narrative praxis, practices and practitioners of entrepreneurial storytelling in organizational practice (Borghoff, 2017, 2018).

“[T]he Greek word 'praxis' refers to actual activity" (ibid.: 619), e.g. meetings, conversations or interactions. Hence, praxis is what people do in practice. From a strategy-as-narrative-practice perspective (Fenton \& Langley, 2011), praxis goes alongside with the "making of" other discursive products like written texts (for example business plans, concept papers). These products are generated by practices, which, in turn "refer to shared routines of behavior, [...] procedures for thinking, acting and using 'things"' (Whittington, 2006: 619), as well as to typical narrative processes, techniques or tools (Fenton \& Langley, 2011: 1173). Processes and products of text- and image-based communication are also associated with the concept of design (Roth \& Spitzmüller, 2007; Weber, 2008). Finally, practitioners are strategic actors who both perform activities and implement the practices of these activities (Whittington, 2006: 619). Practitioners typically interact as individuals or groups of players. The latter often form so-called "communities of practice" (Wenger et al., 2011: 9-11; Wenger et al., 2002; Wenger, 1998; Rüegg-Stürm \& Grand, 2015: 179) and "networks of practice" or NoPs (Wenger et al., 2011: 9-11; Agterberg et al., 2010). ${ }^{1}$

Against this background, the following research questions were developed:

- Which narrative patterns (praxis/products) lead to the constitution of entrepreneurial storytelling? What specific narratives can be reconstructed?

- Which narrative processes (practices/designs) do practitioners use? What do they tell about what they do and how they do it?

- Which actors and groups of players (practitioners/networks) are linguistically present within the discourse?

9 To begin with, the theoretical framework is outlined, highlighting the interdisciplinary approach of the multifaceted phenomenon of entrepreneurial storytelling. After discussing the research approach and applied methods, the context of the two case studies is specified. In subsequent sections, key findings are presented and results are discussed. The paper concludes with implications for science and organizational practice.

\section{Theory: entrepreneurial storytelling as an interdisciplinary phenomenon}

In the context of social constructivism (Weick, 1995), practice turn (Schatzki, 2001), strategy-as-practice (Whittington, 2006), narrative turn (Fenton \& Langley, 2011), "communication constitutes organization-paradigm" (Schoeneborn, 2013; Cooren, 2015; McPhee \& Zaug, 2009), narratological management and organization research (Boje, 2001, 2008, 2011; Czarniawska, 1996, 1997, 1998, 2004), strategic organizational communication (Zerfass, 2010; Jakobs, 2008; Bruhn, 2008) and organizational linguistics (Stahl \& Menz, 
2014; Müller, 2008; Habscheid, 2003), this paper aims to develop a grounded theory for a special type of organizational storytelling (Schach, 2015; Herbst, 2014; Ettl-Huber, 2014; Stücheli-Herlach \& Perrin, 2013), namely entrepreneurial storytelling. Storytelling is also becoming increasingly relevant in the field of entrepreneurship. Not only researchers but also entrepreneurial practitioners are concerned with entrepreneurial storytelling, a very young field of research that has rarely been explored in the context of organizational development.

\subsection{Defining entrepreneurship}

11 Entrepreneurship is a process in which new entrepreneurial opportunities and their implementation in marketable products and services are identified (Fueglistaller et al., 2016: 6-8). According to Bygrave and Hofer (1991: 14), "[the] entrepreneur is someone who perceives an opportunity and creates an organization to pursue it." Stevenson and Jarillo (1990: 18) declare entrepreneurship to be a new management approach: "Entrepreneurship is a process, by which individuals-either on their own or inside an organization-pursue opportunities without regard to the resources they currently control." In organizations employees too can become intrapreneurs, institutional entrepreneurs (Czarniawska, 2013: 89-91) or corporate entrepreneurs (Schmelter, 2009).

\subsection{Storytelling, narrative and entrepreneurship}

Lounsbury and Glynn found

[...] that stories play a critical role in the processes that enable new businesses to emerge. Stories that are told by or about entrepreneurs define a new venture in ways that can lead to favorable interpretations of the wealth creating possibilities of the venture; this enables resource flows to the new enterprise. (2001: 546)

13 Villanueva et al. (2013: 1) also investigated the role of storytelling in the process of resource acquisition and show how entrepreneurial stories can influence perception and judgments of potential investors with regard to the legitimacy of new businesses. Smith and Anderson (2004: 126) state

[that] there is a primary relationship between storytelling and entrepreneurship because the communication of value is obviously central to the practice of entrepreneurship, because the entrepreneur "takes between" creating and extracting the value of their product or service. Storytelling is very similar, in that it recounts tales to communicate general values such as the benefits of enterprise and specific values such as appropriate behaviours.

Furthermore, "storytelling and story-making" (ibid.) serve as potential metaphors for conceptualizations and re-conceptualizations of entrepreneurial activity (ibid.: 127). Boje and Saylors (2015: 199) anticipate the following apodictic premise: "Entrepreneurship is storytelling". The process of identification, supply and mobilization of resources, and the telling of the story that makes the company an expedient fiction, are all functions of storytelling. The resulting construction of meaning, i.e. "sensemaking" (Weick, 1995), in and for enterprises evolves from so-called "entrepreneurial narratives", i.e. narrative patterns and processes of performance.

15 As for a differentiation between narrative and story, Czarniawska (2004) states that narrative consists of an initial state, actions or events and a final state, such as, for example, "The baby cried. The mommy picked it up." (ibid.: 19). A story, however, is an 
"emplotted" (ibid.) narrative. The narrative dramaturgy (plot) consists of four phases: exposition (states, places, time, people involved), complication (presentation of unusual actions or events), resolution (positive or negative resolution of the complication), coda (results, perspectives, opinion of the narrator). To proceed with the previous example, the following sentences form a story: "The baby cried. The mommy picked it up. The baby stopped crying." (ibid.) Roland Barthes offers a much more comprehensive description of narratives, showing its indwelling omnipresence:

The narratives of the world are numberless. Narrative is first and foremost a prodigious variety of genres, [...] carried by articulated language, spoken or written, fixed or moving images, gestures, [...] narrative is present in myth, legend, fable, tale, novella, epic, history, tragedy, drama, comedy, mime, painting... stained glass windows, cinema, comics, news item, conversation. [...] Narrative is present in every age, [...] place, [...] society [...]. All classes, all human groups, have their narratives [...] Narrative is international, transhistorical, transcultural: it is simply there, like life itself. (1977: 97)

\subsection{Storytelling, design and entrepreneurship} storytelling has also become relevant in design research ${ }^{2}$ (Brandes et al., 2009; Grand \& Jonas, 2012: 167). In this context, the terms storytelling and design show a close relationship. By writing down how something could be designed and reflecting on the proper story to be told, the design is produced (Brandes et al., 2009: 188).

According to Grand (2012: 155-157) design processes are geared towards the future and thus eventually create potentially successful futures for organizations. In this context Grand also speaks of "Design Fiction [...] [that] uses design... to tell stories" (ibid.: 167.). Design implies both design processes like projecting, creating, constructing as well as methods of materialization, experimentation and reflection (ibid.).

18 This understanding of design shows interconnections with the emergence of entrepreneurship, entrepreneurial storytelling and the constitution of enterprises or organizations which is reflected in terms such as: "entrepreneurial designs" (Günter, 2008: 39), "organizational design" (Baecker, 2003: 300-302), "organisation creation" (Gartner, 2012), "creating the enterprise" (Gartner and Bellamy, 2009), "venture creation" (Gartner, 2004a), "business creation" (Gartner, 2004b).

19 According to Gartner et al. (1992: 17, cited in O'Connor, 2004: 105), “[e]merging organizations are elaborate fictions of proposed possible future states of existence". He compares the telling of stories about entrepreneurial activity and interaction with a hypothesis generation about "how the world might be: how the future might look and act." (2007: 614) Entrepreneurial stories seek to familiarize with the unknown and foreign by framing enterprises within new terms (often metaphors or analogies) that are understandable, comprehensible and therefore legitimate (Salancik \& Leblebici, 1988, cited in Lounsbury \& Glynn, 2001: 549). Therefore, narrative approaches are powerful tools to firstly explore "what entrepreneurs (or others) say about what they do" (Gartner, 2007: 616) and secondly to analyze these stories (ibid.: 613). 


\section{Method: narrative and discourse analysis}

The research was designed as an explorative case study (Yin, 2014) following a mixed methods approach (Kuckartz, 2014: 47-49) with a qualitative sequential design and theoretical foundation. The analysis is based on literature, text corpora and own empirical data collections. Grounded theory (Strübing, 2014; Glaser \& Strauss, 2010; Breuer, 2010) was combined with narrative- and discourse analysis (Bendel Larcher, 2015; Cooren, 2015; Keller, 2011; Viehöver, 2010) to examine a corpus of thirteen texts, including six web texts, two transcribed narrative interviews (Bohnsack, 2014; Küsters, 2009) with practitioners from the case studies and five semi-standardized interviews with artistic alumni and academics of the Swiss art college investigated. The focus of this study is on the analysis of typical narrative, design, networking and discourse patterns (see Fig. 1).

Fig. 1. - Mixed methods case study design: grounded theory, narrative- and discourse analysis

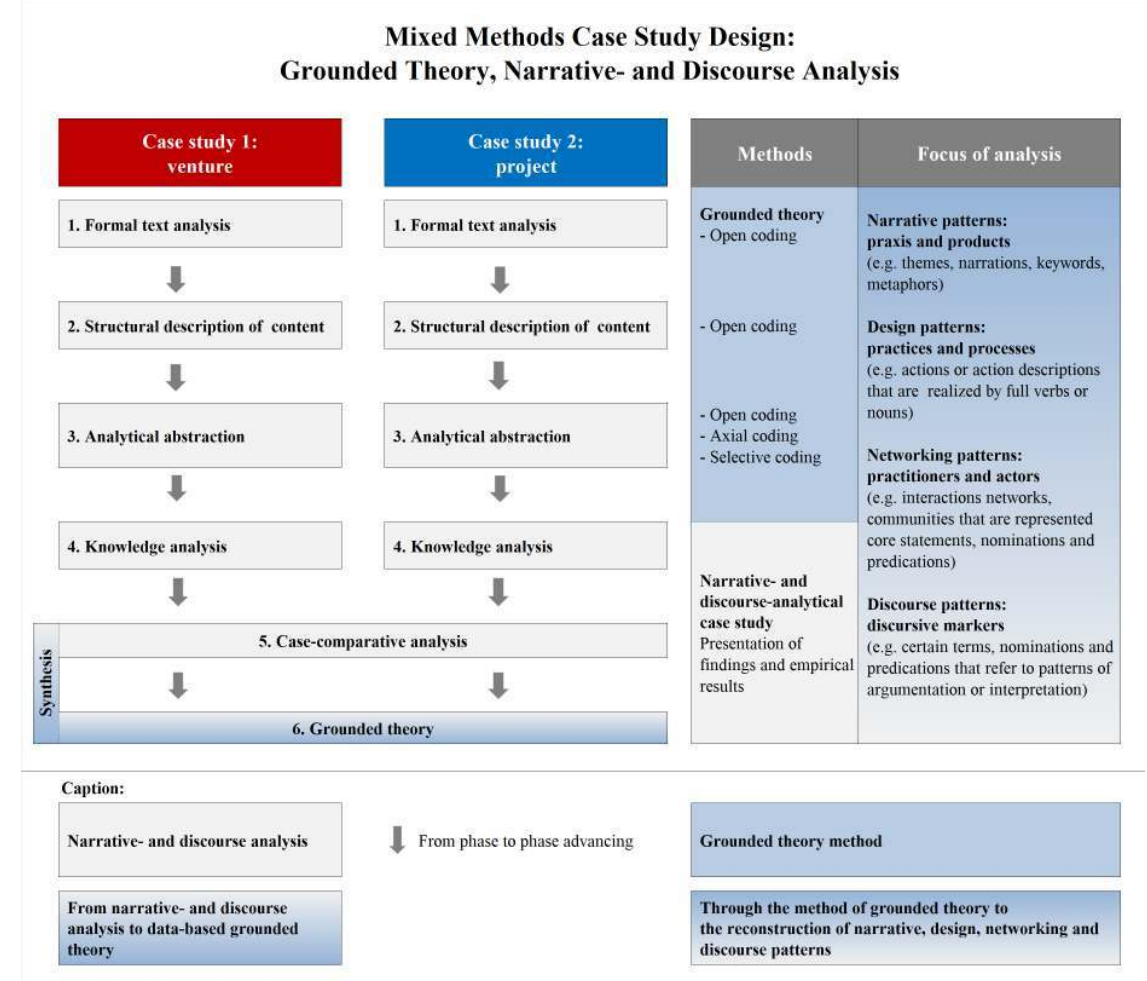

(Own depiction based on Yin, 2014; Bohnsack, 2014; Küsters, 2009; Strübing, 2014; Glaser \& Strauss, 2010; Breuer, 2010; Bendel Larcher, 2015; Cooren, 2015; Keller, 2011; Viehöver, 2010).

\section{Contextualization: culture and creative industries}

The case studies provide an insight into the processes of organization foundation and development. They show foundations from an existing organization, which can be interpreted as a form of "Institutional Intrapreneurship" (Czarniawska, 2013). In both cases, they concern practitioners from the Zurich University of the Arts (ZHdK, 2016), one of Europe's major art colleges in the domains of science, research and education. In recent 
years, various ideas and initiatives have been manifested in concrete projects at this academic institution, as for example, the venture CreativeEconomies (CE, 2016) and the project Methods of Arts (MOA, 2016), which were investigated for the purposes of this study.

The "not for profit"-venture CE (2016), which has been developing from the ZHdK Department of Cultural Analysis (DKV, 2016) since 2014, curates experiments, projects and initiatives that create and test new possibilities of value creation along global networks. Together with its partners, the RISE Management Innovation Lab of the University of St. Gallen (RISE, 2016) and the "Critical Thinking" Initiative (CTI, 2016) of the Swiss Federal Institute of Technology in Zurich (ETH), the venture discusses alternative opportunities for value creation in global networks and develops standards for value creation in culture, technology, business and science.

The project MOA, founded in 2013 in Cologne, is a series of international German and English video interviews with contemporary artists from the various submarkets of the cultural and creative industries sector (see Fig. 2; Weckerle \& Theler, 2010: 10). The project explores key questions about the process of "art making" and artistic methods within the framework of art production. By means of the artistic process of value creation it uncovers different approaches, concepts, strategies, methods, ideas and positions, such as the personality of the artist, concept ideas, material, tools and media, creation and production, artwork, publications and mediation.

Fig. 2. - The 13 submarkets of the cultural and creative industries sector

\begin{tabular}{|c|c|c|c|}
\hline & \multicolumn{3}{|c|}{ The 13 Submarkets of the Cultural and Creative Industries Sector } \\
\hline & Submarket & $\begin{array}{l}\text { Freelancers and self- } \\
\text { employed persons }\end{array}$ & Enterprises and businesses \\
\hline 1. & Music & $\begin{array}{l}\text { Composers, musicians, } \\
\text { music teachers, sound } \\
\text { engineers, } \\
\text { interpreters, music } \\
\text { ensembles }\end{array}$ & $\begin{array}{l}\text { Instrument manufacturing, music publishing, } \\
\text { phonogram production, agency, music shop, } \\
\text { presenter, club, musical, festival, commercial } \\
\text { music school }\end{array}$ \\
\hline 2. & Books & Writers, authors & $\begin{array}{l}\text { Book publishing, intermediate publishing, } \\
\text { book trade, agency }\end{array}$ \\
\hline 3. & Art market & $\begin{array}{l}\text { Fine artists, restorers, } \\
\text { art teachers }\end{array}$ & $\begin{array}{l}\text { Gallery, art trade, museum shop, commercial } \\
\text { art exhibition }\end{array}$ \\
\hline 4. & Film industry & $\begin{array}{l}\text { Screen writers, film } \\
\text { actors, } \\
\text { film producers }\end{array}$ & $\begin{array}{l}\text { Film or television production, film rental, } \\
\text { distribution, movie theater }\end{array}$ \\
\hline 5. & Broadcasting & $\begin{array}{l}\text { Moderators, speakers, } \\
\text { producers }\end{array}$ & $\begin{array}{l}\text { Broadcasting or television } \\
\text { company }\end{array}$ \\
\hline
\end{tabular}




\begin{tabular}{|c|c|c|c|}
\hline 6. & Performing arts & $\begin{array}{l}\text { Performing artists, } \\
\text { artists, } \\
\text { dancers, cabaret artists }\end{array}$ & $\begin{array}{l}\text { Commercial theatre, musical agency, variety } \\
\text { theater, cabaret }\end{array}$ \\
\hline 7. & Design industry & $\begin{array}{l}\text { Designers, } \quad \text { applied } \\
\text { artists }\end{array}$ & $\begin{array}{l}\text { Industrial design agency, product design, } \\
\text { graphic design, } \\
\text { visual design, web design }\end{array}$ \\
\hline 8. & Architecture & $\begin{array}{l}\text { Architects, town and } \\
\text { country planners }\end{array}$ & $\begin{array}{l}\text { Construction and civil engineering, interior } \\
\text { design, landscape design }\end{array}$ \\
\hline 9. & Advertising & $\begin{array}{l}\text { Ad writers, copywriters, } \\
\text { advertisers }\end{array}$ & Advertising agency, advertising spread \\
\hline 10. & $\begin{array}{l}\text { Software and } \\
\text { games }\end{array}$ & $\begin{array}{l}\text { Software engineers, } \\
\text { game developers }\end{array}$ & $\begin{array}{l}\text { Software consulting and } \\
\text { development, software publishing, } \\
\text { programming, agency }\end{array}$ \\
\hline 11. & Arts and crafts & $\begin{array}{l}\text { Artisans, gold- and } \\
\text { silversmiths }\end{array}$ & $\begin{array}{l}\text { Arts and crafts, processing of } \\
\text { jewels and gemstones, } \\
\text { manufacturing jewelry, gold- and silversmith } \\
\text { work }\end{array}$ \\
\hline 12. & Press & $\begin{array}{l}\text { Journalists, } \\
\text { producers }\end{array}$ & Press publishing, press trade, press archives \\
\hline 13. & $\begin{array}{l}\text { Phonotechnical } \\
\text { sector }\end{array}$ & & $\begin{array}{l}\text { Producers and retailers of film, broadcasting } \\
\text { and phonotechnical devices }\end{array}$ \\
\hline
\end{tabular}

(Own depiction in the style of Weckerle \& Theler, 2010: 13)

\section{Findings: entrepreneurial storytelling as narrative practice}

In the following section the key findings of the provisional developed grounded theory for entrepreneurial storytelling in the cultural and creative industries sector are presented.

\subsection{Entrepreneurial narration}

Four typical narrative core patterns could be reconstructed (see Fig. 3). The founder narratives tell about the entrepreneurs themselves and show references to the concept of the curator (curator narrative) as a dynamic mix of producers, artistic directors, mediators, managers, entrepreneurs, directors, chief executive officers, designers or stage directors. As part of the entrepreneurial process, founding narratives feed on the organization narratives of a "venture" and a "project", on the one hand, and the brand narratives of "CreativeEconomies" and "Methods of Arts" on the other. Brands include the name of the 
brand, the trademark and the packaging or design of a product or service (Esch, 2014: 308-310). ${ }^{3}$ Both, the venture and the project share a "not for profit" opportunity narrative and the ownership narrative of "shared authorship" and trademark protection. The business model narrative shows that research in the fields of creative, strategic, entrepreneurship and art research is at the center of the business activities of the venture and the project, as well as teaching and debate. The supply narratives tell about the importance of websites, performances, events, publications, panels and video interviews regarding the entrepreneurial offer. Through the interaction of specific narratives described above, entrepreneurial narration unfolds.

Fig. 3. - Entrepreneurial narration: storytelling products and narratives

\begin{tabular}{|c|c|}
\hline \multicolumn{2}{|c|}{ Entrepreneurial narration: storytelling products and narratives } \\
\hline $\begin{array}{l}\text { Entrepreneurial } \\
\text { storytelling products and } \\
\text { narratives } \\
\text { (selective coding: core } \\
\text { categories) }\end{array}$ & $\begin{array}{l}\text { Specific products and narratives } \\
\text { (most frequent mentions) } \\
\text { (axial and open coding: subcategories and open codes) }\end{array}$ \\
\hline $\begin{array}{l}\text { The entrepreneur } \\
\text { (fragment of founder } \\
\text { narrative) }\end{array}$ & $\begin{array}{l}\text { Concept of the curator as a dynamic mix of producers, } \\
\text { artistic directors, mediators, managers, entrepreneurs, } \\
\text { directors, chief executive officers, designers and stage } \\
\text { directors }\end{array}$ \\
\hline $\begin{array}{l}\text { The entrepreneurial process } \\
\text { (fragment of founding } \\
\text { narrative) }\end{array}$ & $\begin{array}{l}\text { Organization narrative (organization, project, enterprise, } \\
\text { venture), brand narrative ("CreativeEconomics", } \\
\text { "Methods of Arts") Opportunity narrative ("not for profit"), } \\
\text { Ownership narrative ("owner- and authorship: [shared } \\
\text { authorship] Geteilte Autorenschaft?; patent law and trademark: } \\
\text { [How to protect this?] Wie schützt man das?") }\end{array}$ \\
\hline $\begin{array}{l}\text { The entrepreneurial model/ } \\
\text { business field } \\
\text { (fragment of business model } \\
\text { narrative) }\end{array}$ & $\begin{array}{l}\text { Research (creative industries, strategy and } \\
\text { entrepreneurship research, art research), debate and } \\
\text { discourse, teaching and lessons, art mediation and art } \\
\text { education, arts, multilinguism, e-learning and blended } \\
\text { learning }\end{array}$ \\
\hline $\begin{array}{l}\text { The entrepreneurial } \\
\text { product/service } \\
\text { (fragment of supply } \\
\text { narrative) }\end{array}$ & $\begin{array}{l}\text { Website, performances ("stagings"), events, publications, } \\
\text { panels, stories, workshops, video interviews, films, photos, } \\
\text { pictures and images }\end{array}$ \\
\hline
\end{tabular}




\begin{tabular}{|l|l|l|}
\hline Caption & $\begin{array}{l}\text { Caption } \\
\text { The products and narratives } \\
\text { described above were } \\
\text { determined by means of } \\
\text { selective coding within the scope } \\
\text { of the grounded theory method. }\end{array}$ & $\begin{array}{l}\text { Theans of axial and open coding within the scope of the grounded } \\
\text { theory method. Text in bold letters signals a higher relevance due to } \\
\text { corresponding frequencies in the examined text corpora and } \\
\text { affiliation to the appropriate core categories of products and } \\
\text { narratives. Texts in quotation marks are direct quotes from the } \\
\text { sample. }\end{array}$ \\
\hline
\end{tabular}

(Own depiction)

\subsection{Entrepreneurial design}

26 As far as narrative processes are concerned, four selective key practices may be identified. These are used by the actors linguistically present within the discourse. Based on the developed grounded theory category system they were conceptualized with the following newly created terms:

27 - Curating and innovating

The key practice of curating and innovating comprises specific single narrative practices, e.g. "developing", "experimenting, exploring and testing", "creating and designing". "Curating", "selecting", "filming, cutting and photographing" also play a decisive role in the production of the curatorial innovation design.

- Entrepreneurial strategyzing and organizing

The core practice of entrepreneurial strategizing and organizing is based on single practices like "doing and undertaking", "generating values" or "institutionalizing". Likewise, the entrepreneurial strategy design implies "agenda setting", "decision making" and practices of "organizing".

- Telling and cooperating

The key practice telling and cooperating encompasses a variety of communication practices, such as "conducting conversation and dialogue", "writing and formulating", "arguing", "storytelling", "retelling", "presenting" or "exposing". The corresponding collaboration design is also formed by "networking" or "community building" practices.

- Researching and learning

Finally, the core practice of researching and learning combines practices of "asking and scrutinizing", "investigating and analyzing", "perceiving and understanding", as well as "learning", "teaching", "explaining" or "mediating". Through the interplay of these single practices, the knowledge design is finally constructed.

As a result of the joint efforts of all practices, the entrepreneurial designs of CE (2016) and MOA (2016) are eventually generated (see Fig. 4). 
Fig. 4. - Entrepreneurial design: storytelling practices and designs

\begin{tabular}{|c|c|}
\hline \multicolumn{2}{|c|}{ Entrepreneurial design: storytelling practices and designs } \\
\hline $\begin{array}{c}\text { Entrepreneurial storytelling practices } \\
\text { and designs } \\
\text { (selective coding: core categories; } \\
\text { axial coding: subcategories) }\end{array}$ & $\begin{array}{l}\text { Specific single practices } \\
\text { (most frequent mentions) } \\
\text { (open coding: open codes) }\end{array}$ \\
\hline \multicolumn{2}{|c|}{ Curating and innovating (curatorial innovation design) } \\
\hline Design and innovation practices (innovation design) & $\begin{array}{l}\text { Create, connect, combine, develop, explore and } \\
\text { experiment, emerge, materialize and produce, design, } \\
\text { generate ideas, initialize }\end{array}$ \\
\hline & Curate, select, "staging", compose \\
\hline Artistic practices (art design) & Film, cut, photograph \\
\hline \multicolumn{2}{|c|}{ Entrepreneurial strategizing and organizing (entrepreneurial strategy design) } \\
\hline $\begin{array}{l}\text { Entrepreneurial practices and corporate management } \\
\text { (entrepreneurial design) }\end{array}$ & $\begin{array}{l}\text { Undertake, "alternative institutionalization", } \\
\text { value creation, business travel, finance, makret } \\
\text { penetration and acquisition of orders, acquire and } \\
\text { mobilize resources }\end{array}$ \\
\hline Strategic practices (strategy design) & $\begin{array}{l}\text { "Decision making", agenda setting, defining goals, } \\
\text { focus, establish and position, lead, rethink, allow free } \\
\text { space and space off time }\end{array}$ \\
\hline Organizational practices (organization design) & Organize, realize tasks and activities \\
\hline \multicolumn{2}{|c|}{ Telling and cooperating (collaboration design) } \\
\hline Communication practices (communication design) & $\begin{array}{l}\text { Engage conversation and dialogue, discuss, } \\
\text { "storytelling" and retelling, describe, write, argue, } \\
\text { have interviews, know and use social media } \\
\text { channels, publish, reference }\end{array}$ \\
\hline Cooperation practices (cooperation design) & $\begin{array}{l}\text { Cooperate, networking and "community } \\
\text { building" }\end{array}$ \\
\hline \multicolumn{2}{|c|}{\begin{tabular}{|l} 
Researching and learning (knowledge design) \\
\end{tabular}} \\
\hline Research practices (research design) & $\begin{array}{l}\text { Ask and scrutinize, investigate and analyze, } \\
\text { observe and perceive, understand, think, do } \\
\text { research, reflect }\end{array}$ \\
\hline Education practices (education design) & Learn, explain, mediate \\
\hline $\begin{array}{l}\text { Caption } \\
\text { The products and narratives described above were } \\
\text { determined by means of selective coding within the } \\
\text { scope of the grounded theory method. }\end{array}$ & $\begin{array}{l}\text { Caption } \\
\text { The subcategories and open codes listed above were } \\
\text { determined by means of axial and open coding } \\
\text { within the scope of the grounded theory method. Text } \\
\text { in bold letters signals a higher relevance due to } \\
\text { corresponding frequencies in the examined text } \\
\text { corpora and affiliation to the appropriate core } \\
\text { categories of products and narratives. Texts in } \\
\text { quotation marks are direct quotes from the sample. }\end{array}$ \\
\hline
\end{tabular}

(Own depiction)

29 Fig. 5 below shows the interplay between the different key practices and indwelling designs, and how the individual practices mutually interpenetrate one another. For example, "creating" not only influences the curatorial innovation design of organizations and projects, but also the entrepreneurial strategy design. Likewise, "storytelling", and the "retelling" of stories, contribute to the key practice of entrepreneurial strategizing \& organizing. The key practices thus function as open, boundary expanding and continuously changing processes that influence each other reciprocally. This process can be described as a narrative act of "entrepreneurializing" (a new term created by the author during the research process) and a typical form of organizational practice. At the same time, "story-making and story-telling" (Smith \& Anderson, 2004: 127) occur simultaneously. In this sense entrepreneurial storytelling is suggested to be reconstructed as a curatorial, innovative, entrepreneurial, strategic, collaborative and knowledge-driven design process. 
Fig. 5. - "Entrepreneurializing": key practices and designs of entrepreneurial storytelling

"Entrepreneurializing":

Key Practices and Designs of Entrepreneurial Storytelling
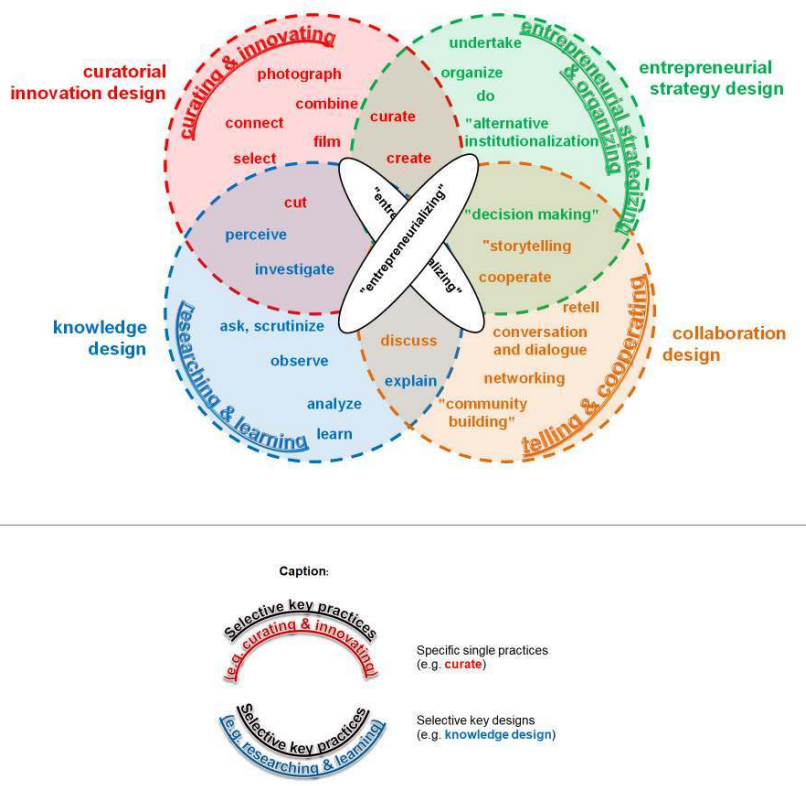

(Own depiction)

\subsection{Entrepreneurial network}

The entrepreneurial network of actors and groups of players linguistically present in the discourse feeds on relevant submarkets of the cultural and creative industries sector such as the press and advertising market, institutions and disciplines from research and science, cultural and creative actors (above all artists from the arts and performing arts market, design, film and music industry) as well as other "highly diverse", "important" or "established" individual actors, organizations, institutions ("collocated organizations", "hybrids" "new constellations"), and the economy as a whole:

Fig. 6. - Entrepreneurial network: storytelling practitioners and networks

\begin{tabular}{|l|l|}
\hline \multicolumn{2}{|l|}{ Entrepreneurial network: storytelling, practitioners and networks } \\
\hline $\begin{array}{l}\text { Entrepreneurial storytelling } \\
\text { practitioners and networks } \\
\text { (selective coding: core categories) }\end{array}$ & $\begin{array}{l}\text { Specific practitioners and narratives } \\
\text { (most frequent mentions) } \\
\text { (axial and open coding: subcategories and open codes) }\end{array}$ \\
\hline $\begin{array}{l}\text { Submarkets of the cultural and } \\
\text { creative industries }\end{array}$ & $\begin{array}{l}\text { Press and advertising market, design industry, } \\
\text { broadcasting }\end{array}$ \\
\hline Research and science & $\begin{array}{l}\text { Institutions and science disciplines (art college, } \\
\text { other relevant institutions), researchers }\end{array}$ \\
\hline
\end{tabular}




\begin{tabular}{|l|l|l|}
\hline Organizations, institutions & $\begin{array}{l}\text { "collocated organizations and industries", "hybrids } \\
\text { and entirely new constellations" }\end{array}$ \\
\hline Individual actors & $\begin{array}{l}\text { "highly diverse actors", "important actors", } \\
\text { "established actors", "actors shaping diverse spheres } \\
\text { of action" }\end{array}$ \\
\hline $\begin{array}{l}\text { Cultural and creative actors and } \\
\text { organizations }\end{array}$ & $\begin{array}{l}\text { Artists (especially fine artists), museums and } \\
\text { exhibitions, designers, film technicians, music and } \\
\text { performing arts actors }\end{array}$ \\
\hline $\begin{array}{l}\text { Caption } \\
\text { The products and narratives described } \\
\text { above were determined by means of } \\
\text { selective coding within the scope of the } \\
\text { grounded theory method. }\end{array}$ & $\begin{array}{l}\text { CEO, project and department heads, managers, } \\
\text { entrepreneurs, enterprises } \\
\text { signals a higher relevance due to corresponding } \\
\text { frequencies in the examined text corpora and affiliation to } \\
\text { the appropriate core categories of products and narratives. } \\
\text { Texts in quotation marks are direct quotes from the } \\
\text { sample. }\end{array}$ \\
\hline $\begin{array}{l}\text { Caption subcategories and open codes listed above were } \\
\text { The }\end{array}$ \\
\hline
\end{tabular}

(Own depiction)

\subsection{Entrepreneurial story}

The analysis of the narrative interview with practitioners of MOA (2016) points to the basic narrative of the broker: the story of the project begins in the German city Cologne, where the lecturers pursue a common wish (Wunsch): the development of a catalog of questions (Fragenkatalog) for a methodological guide (Methoden-Leitfaden) and open box ( offener Zettelkasten) which they curate as a research-, mediation-, network- and acquisition tool (Research-, Forschungs-, Vermittlungs-, Netzwerk- und Akquise-Tool) in order to extract from the sheer mass of ever-increasing artist positions (Künstlerpositionen) those beads (Perlen) and heart collections (Herzkollektionen) which show the new changed self-understanding of the new or next artist in its multiplicity. The term curating ( kuratieren) in this context means to be concerned about the way in which a project may develop further products or side branches (Seitenäste). It is like a brokerage disposition ( Vermittlungsdispositiv), which becomes part of the exhibition and thus also part of the project. The narrative language use in the project MOA (2016) reflects the basic story of the art-loving broker/curator, who at the same time appears as striving and industrious. To summarize, the entrepreneurial project-story of "busy brokers and curating tooligans" was reconstructed (a newly created term that refers to professional practitioners making frequent use of "tools" such as excel lists, organization charts or other visual tools to perform their work).

Looking at the narrative interview analysis of the venture CE (2016), the basic narrative of the traveler was reconstructed: The entrepreneurs start as "greenhorns", and use a 
"window of opportunity" by taking a trail (Spur) and travelling (reisen) to distant places like "Hong Kong", "Venice" or "London" to make "risky projects" part of their venture in "diverse fields and spheres of action". Doing this with the aim of "value creation" and "creative destruction", they finally return as heroes (Helden), to be subsequently challenged to finally protect (beschützen) what they created within the institutional context of the ZHdK (2016). The basic story of the venture reflects, on the one hand, the heroic journey of an adventurer, discoverer and conqueror in analogy to the discovery of America by Christopher Columbus in 1492. On the other hand, the narrative of the protector in the sense of a guardian, but also a protector from danger was identified. To sum up, the entrepreneurial hero-story of simultaneous conquering adventurers and preserving guardians was reconstructed.

\subsection{Entrepreneurial discourse and value creation}

The findings suggest that, in addition to narrative praxis, practices and practitioners, specific discursive markers play a constitutive role in entrepreneurial discourse (see Fig. 7 below). Thus, social issues such as innovation, renewal and change or "digital disruption" have a significant impact on the business model narrative, which tells stories of "e-learning and blended learning". Likewise, the diverse language use in terms of spatial dimensions (e.g. "global level", "Hong Kong", "China", "Russia") suggests that the supply narratives of CE (2016) and MOA (2016) (e.g. website, panels) are international and multi-lingual. This can also be inferred from the frequent use of English expressions in the narrative interviews conducted in German. Speaking of cultural, social, scientific, economic and organizational contexts, a close connection to the entrepreneurial network can be concluded insofar as the actors (submarkets of the cultural and creative industries sector, cultural and creative actors, research and science) work in the same contexts. The new forms of institutionalization also indicate a relation between this discourse topic and entrepreneurial storytelling practices ("institutionalizing"). Similarly, the discursive terms "hybrid" and "spin-off" denote a close connection with the entrepreneurial single practice of "alternative institutionalization", or the term "laboratories" with the single practice of "exploring, experimenting, testing". In the same way, the discourse topics "emergence" and "boundary expanding" are connected with the single practice "emerging and arising". In this sense, discursive markers appear as a "kit" holding together the entire structure of entrepreneurial storytelling as a narrative practice. They not only influence entrepreneurial narration, design and network, but also contribute significantly to entrepreneurial value creation through the process of " entrepreneurializing" (see Fig. 5). This, in turn, is constituted by the interplay between praxis, practices and practitioners of entrepreneurial storytelling, which are closely linked and can be underpinned by numerous examples (e.g. narrative product: curator narrative; narrative practice: "to curate"; narrative practitioner: "curator"; narrative product: "film"; narrative practice: "to film", narrative practitioner: "camera operator").

Fig. 7. - Entrepreneurial discourse: storytelling discursive markers

Entrepreneurial discourse: storytelling discursive markers 


\begin{tabular}{|c|c|}
\hline $\begin{array}{l}\text { Entrepreneurial storytelling } \\
\text { discursive markers } \\
\text { (selective coding: core categories) }\end{array}$ & $\begin{array}{l}\text { Specific discursive markers } \\
\text { (most frequent mentions) } \\
\text { (axial and open coding: subcategories and open codes) }\end{array}$ \\
\hline Spatial dimensions and contexts & $\begin{array}{l}\text { Global level, "Hong Kong", "Asia", "China", } \\
\text { "Switzerland", European cities ("London", "Venice", } \\
\text { "Zurich", "Cologne"), Russia, USA, cultural, social, } \\
\text { scientific, economic and organizational contexts }\end{array}$ \\
\hline Dynamics, progress, trends & $\begin{array}{l}\text { “"force fields' as 'extreme poles"', innovation, renewal, } \\
\text { change, "digital disruption" }\end{array}$ \\
\hline Temporal dimensions & $\begin{array}{l}\text { Present ("today experimenting"), past ("in history"), } \\
\text { future ("possible future worlds", "future-oriented", } \\
\text { "attractive, desirable, equitable, efficient... future") }\end{array}$ \\
\hline $\begin{array}{l}\text { New forms } \\
\text { institutionalization }\end{array}$ & $\begin{array}{l}\text { "Creative Economy Model", new business models, } \\
\text { laboratories, hybrid organizations, spin-offs, collaborative } \\
\text { formats, incubator }\end{array}$ \\
\hline $\begin{array}{l}\text { Caption } \\
\text { The products and narratives } \\
\text { described above were determined } \\
\text { by means of selective coding within } \\
\text { the scope of the grounded theory } \\
\text { method. }\end{array}$ & $\begin{array}{l}\text { Caption } \\
\text { The subcategories and open codes listed above were determined } \\
\text { by means of axial and open coding within the scope of the } \\
\text { grounded theory method. Text in bold letters signals a higher } \\
\text { relevance due to corresponding frequencies in the examined text } \\
\text { corpora and affiliation to the appropriate core categories of } \\
\text { products and narratives. Texts in quotation marks are direct } \\
\text { quotes from the sample. }\end{array}$ \\
\hline
\end{tabular}

(Own depiction)

\section{Discussion and implications for science and organizational practice}

The analysis shows that entrepreneurial storytelling influences the creation, development and design of new projects and enterprises. Entrepreneurial thinking and doing of practitioners or networks in the cultural and creative industries sector unfurls within the stories which are told about the investigated organizations. In this regard, the four key practices play a central role in the submarkets of the cultural and creative industries sector by creating both entrepreneurial narration and design of the venture $\mathrm{CE}$ (2016) and the project MOA (2016). Against the background of the analysis, the reconstruction of a curatorial innovation design as a key practice of entrepreneurial storytelling is interesting, seeming to be peculiar to the discursive context of the cultural and creative industries sector. Likewise, the constitution of the knowledge design is promising, especially regarding the emergence of research-based knowledge and educational entrepreneurship. Therefore, it might be useful to examine whether these key practices can also be observed in other markets and contexts and be classified as 
relevant for other fields of discourse (e.g. technology, industry, trade, service sector, health, etc.).

Based on these findings, reciprocal references to scientific concepts of design and innovation research can be established. Aspects of both theories are also reflected in the reconstructed curatorial innovation design. This can be demonstrated by single practices such as "innovating", "idea creation" or "prototyping". Against the background of the institutional embedding in the context of the ZHdK (2016), it can be assumed that these reciprocal references might have a positive effect on the international positioning of the college, for instance, by further strengthening the entrepreneurial self-understanding of the college in the public mind, in the sense of corporate "entrepreneurializing". On the other hand, the positioning of MOA (2016) and CE (2016) at the Swiss arts college ZHdK (2016) would be further reinforced by the fact that the current opportunity narrative of a predominant "not for profit" use might eventually develop into a commercially independent new market solution (e.g. spin-off).

In view of the synchronization of organizational discourse (Perrin \& Wyss, 2016: 253), corresponding communication requires the linguistically present narratives in the current entrepreneurial discourse to be taken up again in the context of strategic communication activities of the ZHdK (2016). This implies that both intrapreneurial stories about "curating tooligans and busy brokers" and "conquering adventurers and preserving guardians" have to be consistently added and retold. In this sense, specific narratives can be reused as knowledge-constitutive elements for intra- and entrepreneurial storytelling, discourse and value creation of the academic institution ZHdK (2016), the venture CE (2016) and the project MOA (2016).

This research has potential implications for the emerging academic field of entrepreneurial storytelling:

- Launching of other case studies in the field of culture and creative industries to identify further typical discursive markers; deeper penetration into individual submarkets to compare profession-specific practices of entrepreneurial storytelling in art production in view of typical similarities and differences.

- Further exploration of the process of "entrepreneurializing" in particular with regard to interdisciplinary references to the following fields: communication constitutes organization, narrative management- and organizational research, strategy communication, organizational storytelling, design, entrepreneurship and innovation research.

- Trans- and multidisciplinary research in view of the generalizability of the provisional grounded theory to examine whether similar phenomena can also be observed in other areas such as technology, industry, services, etc.

In view of organizational practice the findings have potentially significant applications for entrepreneurial actors and communicators alike, since the results may be transferred to developing new tools and formats for teaching, coaching and consulting (e.g. lectures, further education and training in the disciplines of organizational communication, organizational development, entrepreneurship, innovation management, design thinking, specifically in art mediation and communication). They can also be conveyed as a scientifically sound method and tool for coaching and consulting self-employed persons, freelancers, entrepreneurs, intrapreneurs and organizations as a whole. 
To conclude, this contribution has shown entrepreneurial storytelling as a multifaceted, interdisciplinary phenomenon serving practitioners to create their own projects or to establish new organizations whether in the cultural and creative industries sector, (further) education, research or consulting. People who want to position their project or organization vis à vis the public are encouraged to tell what they do and how they do it. In the end, this explains why entrepreneurial storytelling and narrative are rediscovered by practitioners, researchers and academics alike. After all, everyone wants to write success stories.

\section{BIBLIOGRAPHY}

ABOLHASSAN Ferri (2017), The Drivers of Digital Transformation, Why There's No Way Around the Cloud, Cham: Springer International Publishing.

AGERBERG Marlous, VAN DEN HOOFf Bart, huYSMAN Marleen \& SOEKIJAD Maura (2010), "Keeping the Wheels Turning: The Dynamics of Managing Networks of Practice", Journal of Management Studies, 47, 85-108, <http://dx.doi.org/10.1111/j.1467-6486.2009.00867.x>.

BAECKER Dirk (2003), Organisation und Management, Frankfurt am Main: Suhrkamp.

BAECKER Dirk (2007), Studien zur nächsten Gesellschaft, Frankfurt am Main: Suhrkamp.

BARTHES Roland (1977), “Introduction to the Structural Analysis of Narratives”, R. Barthes (ed.), Image-Music-Text, Glasgow: William Collins, 79-124.

BENDEL LARCHER Sylvia (2015), Linguistische Diskursanalyse, Ein Lehr- und Arbeitsbuch, Tübingen: Narr Francke Attempto.

BOHNSACK Ralf (2014), Rekonstruktive Sozialforschung: Einführung in qualitative Methoden, Opladen/ Toronto: Barbara Budrich.

BOJE David M. (2001), Narrative methods for organizational \& communication research, London: Sage.

BOJE David M. (2008), Storytelling organizations, Los Angeles: Sage.

BоJE David M. (2011), Storytelling and the future of organizations an antenarrative handbook, New York: Routledge.

BOJE David M. \& SAYLORS Rohny (2015), "Posthumanist entrepreneurial storytelling, global warming, and global capitalism", P. Genoe Mc Laren, A. J. Mills \& T. G. Weatherbee (eds), The Routledge Companion to Management and Organizational History, New York: Routledge, 197-205. BORGHOFF, Birgitta (2017), “Entrepreneurial Storytelling: Narrative Praktiken und Designstrategien in der Projekt- und Organisationsentwicklung”, D. Perrin \& U. Kleinberger (eds), Doing Applied Linguistics. Enabling Transdisciplinary Communication, Berlin/Boston: Walter de Gruyter, 175-184.

BORGHOFF Birgitta (2018), "Entrepreneurial Storytelling as Narrative Practice in Project- and Organizational Development, Findings of a narrative- and discourse analytical case study in Switzerland", E. Innerhofer, H. Pechlaner \& E. Borin (eds), Entrepreneurship in culture and creative 
industries, Perspectives from Companies and Regions (FGF Studies in Small Business and Entrepreneurship), Wiesbaden: Springer.

BOUNFoUR Ahmed (2016), Digital Futures, Digital Transformation, From Lean Production to Acceluction, Cham: Springer International Publishing.

BRANDES Uta, ERLHOFF Michael \& SCHEMMANN Nadine (2009), Designtheorie und Designforschung, Paderborn: Wilhelm Fink.

BREUER Franz (2010), Reflexive Grounded Theory, Eine Einführung für die Forschungspraxis, Wiesbaden: VS.

BRUHN Manfred (2008), “Integrierte Kommunikation”, M. Meckel \& B. F. Schmid (eds), Unternehmenskommunikation, Kommunikationsmanagement aus Sicht der Unternehmensführung, Wiesbaden: Gabler,513-556.

BYGRAVE William \& HOFER Charles (1991), "Theorizing about Entrepreneurship”, Entrepreneurship Theory and Practice, 16, 13-22.

CE [CreativeEconomies] (2016), Website, <http://www.creativeeconomies.com> (accessed 10 December 2016).

DKV [Departement Kulturanalysen und Vermittlung, ZHdK] (2016), Website, <https:// www.zhdk.ch/index,php?id=418> (accessed 10 December 2016).

COOREN François (2015), Organizational discourse, Communication and constitution (Key themes in organizational communication), Cambridge: Polity Press.

CTI [«Critical Thinking»-Initiative, ETH Zürich] (2016), Website, <https://www.ethz.ch/en/theeth-zurich/main-focus-areas/critical-thinking-initiative.html> (accessed 10 December 2016).

CZARNIAWSKA Barbara (1996), Translating organizational change, 56, De Gruyter studies in organization, Berlin: De Gruyter.

CZARNIAWSKA Barbara (1997), Narrating the organization, Dramas of institutional identity (New practices of inquiry), Chicago, Ill: University of Chicago Press.

CZARNIAWSKA Barbara (1998), A narrative approach to organization studies, Thousand Oaks, CA: Sage. CZARNIAWSKA Barbara (2004), Narratives in Social Science Research, Thousand Oaks: Sage. CZARNIAWSKA Barbara (2013), “The Tales of Institutional Entrepreneurs”, A. P. Müller \& L. Becker (eds), Narrative and Innovation, New Ideas for Business Administration, Strategic Management and Entrepreneurship, Wiesbaden: Springer VS, 89-117.

DE BEER Estelle (2014), “Creating value through communication”, Public Relations Review, 40(2), 136-143.

ETTL-HUBER Silvia (2014), Storytelling in der Organisationskommunikation, Wiesbaden: Springer. ESCH Franz-Rudolf (2014), Strategie und Technik der Markenführung, ed. München: Vahlen.

FAIRHURST Gail T. (2007), Discursive Leadership: In Conversation with Leadership Psychology, Thousand Oaks: Sage.

FENTON Chris \& LANGLey Ann (2011), "Strategy as Practice and the Narrative Turn", Organization Studies, 32(9), <DOI: 10,1177/0170840611410838>.

FUEGLISTALLER Urs, MÜLLER Christoph, MÜLLER Susan \& VOLERY Thierry (2016), Entrepreneurship, Modelle - Umsetzung - Perspektiven. Mit Fallbeispielen aus Deutschland, Österreich und der Schweiz, Wiesbaden: Springer Gabler. 
GARTNER William B., BIRD Barbara J. \& STARR Jennifer A. (1992), “Acting as if, Differenting entrepreneurial from organizational behavior", Entrepreneurship theory and practice, 13-31. GARTNER William B. (2004a), “The edge defines the (w)hole: saying what entrepreneurship is (not)", D. Hjorth \& C. Steyaert (eds), Narrative and discursive approaches in entrepreneurship, Cheltenham: Edward Elgar (Movements in entrepreneurship), 245-254.

GARTNER William B. (2004b), Handbook of entrepreneurial dynamics, The process of business creation, Thousand Oaks: Sage.

GARTNER William B. (2007), "Entrepreneurial narrative and a science of the imagination", Journal of Business Venturing, 22, 613-627.

GARTNER William B. \& BELLAMY Marlene G. (2009), Creating the enterprise, Mason: Thomson SouthWestern.

GARTNER William B. (2010), ENTER: Entrepreneurial Narrative Theory Ethnomethodology and Reflexivity: An Issue about The Republic of Tea, Clemson: Clemson University Digital Press.

GARTNER William B. (2012), “Entrepreneurship as organisation creation”, D. Hjorth (ed.), Handbook on organisational entrepreneurship, Cheltenham: Edward Elgar, 21-30.

GLASER Barney G. \& STRAUSS Anselm L. (2010), Grounded Theory, Strategien qualitativer Forschung, Bern: Hanser Huber.

GRAND Simon (2012), "Research as design: Promising Strategies and Possible Futures", S. Grand \& W. Jonas (eds), Mapping Design Research, Basel: Birkhäuser,155-176.

GRAND Simon \& JONAS Wolfgang (2012), Mapping Design Research, Basel: Birkhäuser.

HABSCHEID Stephan (2003), Sprache in der Organisation, Sprachreflexive Verfahren im systemischen Beratungsgespräch, Berlin: de Gruyter.

HAUSMANN Andrea (2012), Kunst- und Kulturmanagement, Kompaktwissen für Studium und Praxis, Wiesbaden: VS Verlag für Sozialwissenschaften.

HAUSMANN Andrea (2017), Personalmanagement im Kulturbetrieb: Mitarbeiter erfolgreich gewinnen, führen und entwickeln, Wiesbaden: Springer.

HERBST Dieter (2014), Storytelling, Konstanz: UVK.

HJORTH Daniel \& STEYAERT Chris (2004), Narrative and discursive approaches in entrepreneurship, Cheltenham: Edward Elgar (Movements in entrepreneurship).

JАКовS Eva-Maria (2008), “Unternehmenskommunikation, Arbeitsfelder, Trends und Defizite”, S. Niemeier \& H. Diekmannshenke (eds), Profession \& Kommunikation, Frankfurt am Main: Peter Lang,13-31.

KELLER Reiner (2011), Diskursforschung, Eine Einführung für SozialwissenschaftlerInnen, Wiesbaden: VS.

KLEIN Armin (2009), Leadership im Kulturbetrieb, Wiesbaden: VS Verlag für Sozialwissenschaften. KLEIN Armin (2011), Der Exzellente Kulturbetrieb, Wiesbaden: VS Verlag für Sozialwissenschaften. KONRAD Elmar D. (2006), Unternehmertum und Führungsverhalten im Kulturbereich, Münster: Waxmann.

KONRAD Elmar D. (2010), Kulturmanagement und Unternehmertum, Stuttgart: Kohlhammer. 
KONRAD Elmar D. (2013), “Cultural Entrepreneurship: The Impact of Social Networking on Success”, Creativity and Innovation Management, 22(3), 307-319.

KUCKARTZ Udo (2014), Mixed Methods Methodologie, Forschungsdesigns und Analyseverfahren, Wiesbaden: Springer VS.

KÜSTERRS Ivonne (2009), Narrative Interviews, Grundlagen und Anwendungen, Wiesbaden: VS.

LOUNSBURY Michael D. \& GLYNN Mary Ann (2001), “Cultural Entrepreneurship, Stories, Legitimacy and the Acquisition of Resources”, Strategic Management Journal, 22, 545-564.

MCPHEE Robert D. \& ZAUG Pamela (2009), “The communicative constitution of organisations, A Framework for Explanation", L. L. Putnam \& A. M. Nicotera (eds), Building Theories of Organization, The Constitutive Role of Communication, New York: Routledge, 21-47.

MOA [Methods of Art] (2016), Website, <http://www.methodsofart.net> (accessed 10 December 2016).

MÜLLER Andreas P. (2008), “Aufgabenfelder einer Linguistik der Organisation”, F. Menz \& A. P. Müller (eds), Organisationskommunikation, München: Rainer Hampp, 17-46.

O'CONNOR Ellen (2004), "Storytelling to be real: narrative, legitimacy building and venturing", D. Hjorth \& C. Steyaert (eds), Narrative and discursive approaches in entrepreneurship, Cheltenham: Edward Elgar, 105-124.

PERRIN Daniel \& WYSS Vinzenz (2016), “In die Geschichten erzählen, Die Analyse von Narration in öffentlicher Kommunikation”, M. Meyen \& S. Averbeck-Lietz (eds), Handbuch nicht standardisierte Methoden in der Kommunikationswissenschaft, Wiesbaden: Springer, 241-255.

ROTH Kersten S. \& SPITZMÜLLER Jürgen (2007), Textdesign und Textwirkung in der massenmedialen Kommunikation, Konstanz: UVK.

RÜEGG-STÜRM Johannes \& GRAND Simon (2015), Das St, Galler Management-Modell, Bern: Haupt Verlag.

SALANCIC Gerald R. \& LEBLEBICI Huseyin (1988), "Variety and form in organizing transactions, a generative grammar of organization", N. DiTomao \& S. B. Bacharach (eds), Research in the Sociology of Organizations, 6, Greenwich, CT: JAI Press, 1-31.

SCHACH Annika (2015), Storytelling und Narration in den Public Relations, Eine textlinguistische Untersuchung der Unternehmensgeschichte, Wiesbaden: Springer VS.

SCHATZKI Theodore R, KNORR CETINA Karin \& VON SAVIGNY Eike (2001), The Practice Turn in Contemporary Theory, London: Routledge.

SCHMELTER Ralf (2009), Der Einfluss von Management auf Corporate Entrepreneurship (Gabler Edition Wissenschaft, Entrepreneurship), Wiesbaden: Gabler.

SCHOENEBORN Dennis (2013), “Organisations- trifft Kommunikationsforschung, Der Beitrag der ‘Communication Constitutes Organization'-Perspektive (CCO)”, A. Zerfass, L. Rademacher \& S. Wehmeier (eds), Organisationskommunikation und Public Relations, Forschungsparadigmen und neue Perspektiven, Wiesbaden: Springer VS, 97-115.

SMITH Robert \& ANDERSON Alistair R. (2004), "The devil is in the e-tale, forms and structures in the entrepreneurial narratives", D. Hjorth \& C. Steyaert (eds), Narrative and discursive approaches in entrepreneurship, Cheltenham: Edward Elgar, 125-143.

STAHL Heinz K. \& MENZ Florian (2014), Handbuch Stakeholder-Kommunikation, Überzeugende Sprache in der Unternehmenspraxis, Berlin: Erich Schmidt. 
STEVENSON Howard \& JARILLO J. Carlos (1990), “A Paradigm of Entrepreneurship: Entrepreneurial Management", Strategic Management Journal, 2010(11), 17-27.

STEYAERT Chris (2004), “The prosaics of entrepreneurship”, D. Hjorth \& C. Steyaert (eds), Narrative and discursive approaches in entrepreneurship, Cheltenham: Edward Elgar, 105-124.

STEYAERT Chris (2007), "Of course that is not the whole (toy) story, Entrepreneurship and the Cat's Cradle”, Journal of Business Venturing, 22(5), 733-751.

STRÜBING Jörg (2014), Grounded Theory, Zur sozialtheoretischen und epistemologischen Fundierung eines pragmatistischen Forschungsstils, Wiesbaden: Springer VS.

STÜCHELI-HERLACH Peter \& Perrin Daniel (2013), Schreiben mit System, PR-Texte planen, entwerfen und verbessern, Wiesbaden: Springer VS.

STÜCHELI-HERLACH Peter (2015), "Beratungskommunikation in der Kommunikationsberatung", Working Papers in Applied Linguistics; 8, Winterthur: ZHAW Zürcher Hochschule für Angewandte Wissenschaften, <https://doi.org/10.21256/zhaw-184> (5 January 2017).

VIEHÖVER Willy (2010), “Diskurse als Narrationen”, R. Keller, A. Hirseland, W. Schneider, W. Viehöver (eds), Handbuch Sozialwissenschaftliche Diskursanalyse, Band I, Theorien und Methoden, Opladen: Leske + Budrich, 179-208.

VILLANUEVA Jaume, SAPIENZA Harry J. \& SUDEK Richard J. (2013), "Does it matter how you tell it? How entrepreneurial storytelling affects the opportunity evaluations of early-stage investors", Frontiers of Entrepreneurship Research, 33(19), 1-15.

WEBER Wibke (2008), Kompendium Informationsdesign, Berlin: Springer.

WECKERLE Christoph \& THELER Hubert (2010), Dritter Kreativwirtschaftsbericht Zürich, Zürich: Zürcher Hochschule der Künste.

WEICK Karl E. (1995), Sensemaking in organizations, Thousand Oaks: Sage.

WENGER Etienne (1998), Communities of practice, Learning, meaning, and identity, Cambridge: Cambridge University Press.

WENGER Etienne, MCDERMOTT Richard \& SNYDER William (2002), A guide to managing knowledge, Cultivating Communities of practice, Boston: Harvard Business School Press.

WENGER Etienne, TRAYNER Beverly \& DE LAAT Maarten (2011), Promoting and assessing value creation in communities and networks: a conceptual framework, Rapport 18, AT Heerlen: Ruud de Moor Centrum, Open University of the Netherlands, <http://wenger-trayner,com/resources/ publications/evaluation-framework> (22 February 2017).

WHITTINGTON Richard, (2006), "Completing the practice turn in strategy research", Organization Studies, 27, 613-634

YIN Robert K. (2014), Case study research, Design and methods, Los Angeles: Sage.

ZERFASS Ansgar (2010), Unternehmensführung und Öffentlichkeitsarbeit, Grundlegung einer Theorie der Unternehmenskommunikation und Public Relations, Wiesbaden: VS.

ZERFASS Ansgar, BENTELE Günter, sCHWALBACK Joachim \& MUSCHDA Sherzada (2013), Unternehmenskommunikation aus der Sicht von Vorständen und Kommunikationsmanagern - Ein empirischer Vergleich, Forschungsberichte zur Unternehmenskommunikation Nr. 2, Leipzig: Akademische Gesellschaft für Unternehmensführung und Kommunikation, <http:// www,akademische-gesellschaft,com/fileadmin/webcontent/Research_report/ Forschungsbericht_2_Akademische_Gesellschaft,pdf> (15 February 2017). 
ZHdK (2016), Website, <https://www.zhdk.ch> (accessed 10 December 2016).

\section{NOTES}

1. Whereas a network refers to the relationships, connections and personal interactions among participants who have reasons to connect to solve problems and create knowledge together, a community refers to the development of a shared identity around a topic and a collective intention. Combining network and community, one can say that communities comprise networks of relationships whilst the emergence of networks can be due to members that are committed to a joint enterprise.

2. Design research was originally constituted as research primarily into the process of design, developing from work in design methods, but the concept has been expanded to include research embedded within the process of design, including work concerned with the context of designing and research-based design practice. The concept retains a sense of generality, aimed at understanding and improving design processes and practices quite broadly, rather than developing domain-specific knowledge within any specific professional field of design.

3. The aim of branding is to differentiate the enterprise's performance from the products or services of potential competitors and to clearly position itself within a competitive market.

\section{ABSTRACTS}

Based on an organizational communication perspective, entrepreneurial storytelling is reconstructed as a reciprocal process of "entrepreneurializing". By focusing on two case studies from the Swiss cultural and creative industries sector, narrative praxes, practices and practitioners of entrepreneurial storytelling in project- and organizational development are outlined. Story-making and story-telling about a curatorial, innovative, entrepreneurial, strategic, collaborative and knowledge-driven design process generate entrepreneurial narration, design, networks and organization-specific discourse. This interplay is suggested as the basis for the entrepreneurial story and value creation that shape the narrative identity of projects, organizations and enterprises. In the case studies presented this is constituted through the project-narrative of "curating tooligans and busy brokers" and the entrepreneurial heronarrative of "conquering adventurers and preserving guardians". Implications are discussed to guide future comparable research for the emerging field of entrepreneurial storytelling. In view of the development and transfer of new tools and formats for teaching, coaching and consulting, first applications for professionals are argued.

Dans le cadre de la communication relative aux organisations, la narration entrepreneuriale est abordée comme un processus réciproque d'« entrepreneuriarisation ». L'analyse de deux études de cas relevant du secteur de l'industrie culturelle et créative suisse permet de mettre en lumière la praxis, les pratiques ainsi que les praticiens de la narration entrepreneuriale dans le contexte $\mathrm{du}$ développement de projets et d'organisations. La mise en récit et la narration d'un processus de conception à la fois conservateur, innovant, entrepreneurial, stratégique, collaboratif et fondé sur la connaissance génèrent des narrations entrepreneuriales, des conceptions, des réseaux et des discours spécifiques à l'organisation. Cette interaction est proposée comme le socle de 
l'histoire entrepreneuriale et de la création de valeurs qui façonnent l'identité narrative des projets, des organisations et des entreprises. Dans les deux études de cas présentées ici, ceci se traduit par un récit relatif aux « curatorial 'tooligans' and busy brokers » et aux héros-entrepreneurs en tant qu'«aventuriers victorieux et gardiens de la conservation». Pour terminer, nous présentons quelques futures pistes de recherche dans le domaine émergeant de la narration entrepreneuriale. Compte tenu du développement et du transfert de nouveaux outils et formats d'enseignement, du coaching et du conseil, les premières applications pour les professionnels sont présentées.

\section{INDEX}

Keywords: entrepreneurial storytelling, entrepreneurial narration, entrepreneurial design, “entrepreneurializing", entrepreneurial network, entrepreneurial story, entrepreneurial discourse and value creation

Mots-clés: le récit entrepreneurial, narration entrepreneuriale, conception entrepreneuriale, « entrepreneuriarisation », réseau entrepreneurial, histoire entrepreneuriale, discours entrepreneurial et de création de valeurs

\section{AUTHOR}

\section{BIRGITTA BORGHOFF}

ZHAW School of Applied Linguistics, Winterthur (Switzerland) 